This section provides reactions to current and emerging issues in bioethics.

\title{
Germline Modification and the Burden of Human Existence
}

\author{
JOHN HARRIS
}

\section{Introduction}

The very idea of intervening in the germline of humans, to modify if not human nature at least the genetic endowment of some humans, continues to encounter hostility that is unrelated to the expected benefit or to the safety and efficacy of such procedures. To understand the pervasive hostility to the idea of germline modification, we first need to look at the roots of this hostility in developments in the 1970s. In this article I do not consider issues of safety and efficacy specifically but explore the question of whether there exist principled objections to germline modification in general and to mitochondrial replacement therapy (MRT) in particular. We start with the modern history of this hostility and then, in the second section, examine the arguments against MRT.
In my book On Cloning, published in $2004,{ }^{1}$ I traced the roots of the hostility to germline modification and, incidentally, outlined the techniquethen already widely known - that might eventually make possible the treatment of mitochondrial disease. I noted there that the panic over germline modification began with IVF:

My interest in cloning was kindled
when I started thinking about cloning
in the light of the birth of Louise Brown
on July 25th 1978. I described the tech-
nique that eventually produced Dolly
in a paper published in $1983^{2}$ and
discussed some possible advantages of
the technique in my book The Value of
Life which was published in $1985 .^{3}$

Now that more than 5 million babies ${ }^{4}$ have been born via assisted reproduction technology (ART), pioneered in

This article is based on three public interventions I made recently in an attempt to defend a new, valuable, and both life-saving and life-enhancing therapeutic technology. The technology in question is mitochondrial replacement therapy (MRT). In descending chronological order, these interventions were (1) a workshop of the United States Institute of Medicine of the National Academies Board on Health Sciences Policy entitled "Ethical and Social Policy Considerations of Novel Techniques for Prevention of Maternal Transmission of Mitochondrial DNA Diseases" in Washington, DC (see http://www.iom.edu/Activities/Research/MitoEthics/2015-MAR-31.aspx); (2) a presentation in the United Kingdom Parliament, under the auspices of the Progress Educational Trust, on Monday, February 2, 2015 (on the eve of the historic debate and vote in the U.K. Parliament that gave the go-ahead for mitochondrial transfer); and (3) an article published in the Guardian newspaper in 2012 shortly after the U.K. Human Fertilization and Embryology Authority announced a public consultation on mitochondrial DNA transfer. 
the U.K. by Bob Edwards and Patrick Steptoe, the horrified reaction of so many commentators at the time, which I remember well, ${ }^{5}$ seems hard to credit. There would, it was widely claimed, be unimaginably terrible long-term effects.

As Louise Brown herself said recently: "When I was born they all said it shouldn't be done and that it was messing with God and nature but it worked and obviously it was meant to be." 6

Almost fifteen years after Louise Brown appeared, another famous female baby was born in the United Kingdom thanks to (and despite execrations directed at) British science. This was a baby called Dolly. ${ }^{7}$ So famous was she destined to become and so scientifically significant was she at birth that her arrival on the scene was announced in Nature on February 27, 1997,8 and again the reaction ranged from hostile to hysterical.

The then president of the United States, Bill Clinton, called immediately for an investigation into the ethics of such procedures ${ }^{9}$ and announced a moratorium on public spending on human cloning. President Clinton said, "There is virtually unanimous consensus in the scientific and medical communities that attempting to use these cloning techniques to actually clone a human being is untested and unsafe and morally unacceptable." ${ }^{10}$ George W. Bush reiterated Clinton's hostility to cloning. "I strongly oppose human cloning, as do most Americans. We recoil at the idea of growing human beings for spare parts, or creating life for our convenience."11 From 1998 to 2001, the time span bookended by these two presidential comments, cloning a large creature like a sheep or a human was problematic and certainly far from "safe enough," given the paucity of reasons that were then apparent for cloning humans. However, their remarks and those of others at the time suggested that cloning creatures was unethical in principlenot simply because it was unsafe. Bush did not, for example, note that growing life for our convenience is the reason we humans have been cloning plants for millennia and why animal cloning has recently taken off in a big way.

Cloning is already being used commercially in the livestock industry in some parts of the world for the replication of elite breeding animals. It has been widely reported in the media that products from the offspring of cloned animals have already entered the human food chain in the United States and elsewhere. . . . Following the decision by the US Food and Drug Administration ... that products from cloned animals are safe, food from clones and their offspring can freely enter the marketplace in the US and there is no requirement for these products to be labeled. There remains a voluntary moratorium in place for clones of species other than cattle, pigs and goats until more information is available on these species. ${ }^{12}$

And neither Bush nor Clinton criticized God for her massive program of human cloning (more on this later).

Members of the European Parliament demanded that each EU member "enact binding legislation prohibiting all research on human cloning and providing criminal sanctions for any breach."13 The European Parliament rushed through a resolution on cloning, the preamble of which asserted that

the cloning of human beings ... , cannot under any circumstances be justified or tolerated by any society, because it is a serious violation of fundamental human rights and is contrary to the principle of equality of human beings as it permits a eugenic and racist selection of the human race, it offends against human dignity and it requires experimentation on humans. 
The resolution went on to claim that "each individual has a right to his or her own genetic identity and that human cloning is, and must continue to be, prohibited."14

The European parliamentarians failed to notice that the same right to "her own genetic identity" is violated with the birth of every identical twin. God (or nature) is a habitual and serial cloner, causing such violations of rights in 1 in every 270 births; 3 in every 1,000 human births are clones. This means that, globally, around 400,000 human clones are born every year. ${ }^{15}$ It is difficult to avoid the conclusion that neither God nor nature has any respect for an individual's "right to her own genetic identity" as defined by the European Parliament.

Following swiftly on the tail of the European Parliament, the Additional Protocol to the Convention for the Protection of Human Rights and Dignity of the Human Being with Regard to the Application of Biology and Medicine, on the Prohibition of Cloning Human Beings of the Council of Europe was promulgated in Paris, on January 12, 1998again, one may think, in some haste, if not panic, following the birth of Dolly. The protocol states:

Considering the purpose of the Convention on Human Rights and Biomedicine, in particular the principle mentioned in Article 1 aiming to protect the dignity and identity of all human beings,

[The member states] have agreed as follows:

Article 1

1. Any intervention seeking to create a human being genetically identical to another human being, whether living or dead, is prohibited.

2. For the purpose of this article, the term human being "genetically identical" to another human being means a human being sharing with another the same nuclear gene set.

These statements provide no coherent basis for objection to cloning, nor indeed to germline therapy per se. There are vague references to "human rights" or "dignity" or the importance of "genetic identity" with little or no attempt to explain what these principles are, or to indicate how they might apply to cloning. If, for example, embryo splitting (the deliberate creation of monozygotic twins) proved to confer immunity to some lethal genetic diseases, would we ban this deliberate cloning? I hope not!

In 2001 the United Kingdom government outlawed human reproductive cloning in the hastily drafted Human Reproductive Cloning Act 2001. This hostility to cloning followed closely the pronouncements of many other bodies both in Europe and across the world. It is sometimes claimed ${ }^{16}$ that the extensive outlawing of germline alterations now in place in many countries was the result of a long and thoughtful process. The available evidence does not support this. The consensus against germline interventions per se, as I have indicated previously and argued elsewhere, ${ }^{17}$ is ill-conceived and is now crumbling - witness the recent vote to change the law in the U.K. Parliament ${ }^{18}$ and the willingness of the United States Institute of Medicine of the National Academies to make a serious and objective reassessment of these issues. ${ }^{19}$

The common factors between Louise Brown and the family-name-deficient Dolly were two. First there is the allegedly "synthetic" circumstances of their conception and birth (as if they weren't real female human and animal individuals). The second factor is the claim that their creation involved some unspecified violation of what was variously described as a right to "genetic identity" and, in 
the case of human cloning (that is, the deliberate creation of monozygotic twins), of a right in essence plucked from the air to suit prejudice and scientific illiteracy. This imperative, invented by UNESCO's Bioethics Committee to justify its condemnation of cloning, involves the claim that the human genome must be preserved as "the common heritage of humanity." 20 Those who appeal to this concept not only have come to see the present evolved state of the human genome as the common heritage of humanity but also draw on the almost always unargued claim that the human genome must be frozen, as far as is possible, in perpetuity at this particular evolutionary stage.

UNESCO conveniently ignored the fact that cloning is the only reproductive method that actually does preserve the human genome intact. Indeed, it copies it (sometimes only almost) exactly. Other forms of human reproduction, on the other hand, randomly vary the human genome with each combination of the genetic material of two or more different individuals. What human reproduction does not do very well is improve it. As I argued in my book Enhancing Evolution, ${ }^{21}$ the human genome in its present state is a very imperfect work in progress. The problem is that progress via Darwinian evolution is extremely slow, and the direction unpredictable; all we know is that it will facilitate gene survival. ${ }^{22}$ It is probable that, in the interests of human survival and certainly those of human welfare and well-being, we may simply not be able to wait. For example, we will need to accelerate the development of better resistance to bacteria, disease, viruses, or hostile environments or of the technologies that will be eventually necessary to find, and travel to, habitats alternative to the earth. There are methods to push evolution a little harder in the right direction, and there are, with suitable safety caveats, moral reasons-in addition to some of the appropriate safety measures I have discussed elsewhere ${ }^{23}$ to make use of these methods. We now turn to one specific existing possibility for improvement that involves a germline intervention-namely, mitochondrial replacement therapy.

\section{The Argument: What Are the Pros and Cons of MRT Whereby Healthy Mitochondria from an Unrelated Donor Are Included in an Embryo Containing the Nuclear DNA of Two Other People?}

We should note, before concentrating on MRT, that a recent flurry of papers in Nature and Science discussing possible research and therapy using various genome modification techniqueswhich were almost immediately followed by the announcement that a group in China had used such techniques in human embryos ${ }^{24}$ — are further evidence not only of the scientific viability of methods of modifying the human germline but also of the need to reassess the safety, efficacy, and ethics of the use of such techniques in humans and to move toward a new consensus as to the appropriate conditions for their ultimate acceptability. ${ }^{25}$

In particular, the paper by David Baltimore et al. emphasizes the need for such work to be carried out "in countries with a highly developed bioscience capacity" and ones in which "tight regulation" of such science exists or can be established. ${ }^{26}$ In the U.K. context, for example, any further such modifications that would end up in the genome of an implanted human embryo would have to be licensed by the U.K. regulatory body Human Fertilization and Embryology Authority (HFEA), which was established by act of Parliament in 1990. ${ }^{27}$ Such measures would probably 
also need to be approved separately by Parliament, as has recently happened in the case of MRT. In other words, in the U.K. we have-and for more than 25 years have had-so far adequate and robust safeguards in place. However, these safeguards in the U.K. are the result of prior years of wide public consultation, punctuated by scholarly research and the commissioning of authoritative reports, ${ }^{28}$ and the emergence of a consensus on the way forward should be established and continually reviewed by Parliament where necessary.

I shall now concentrate on the ethics of MRT, which is, from a safety perspective, widely regarded as now good to go. But a number of the considerations we are about to discuss will also apply to the other techniques described in the literature cited previously.

There is a large degree of desperation and not a little callousness in the objections that have been made so far to mitochondrial donation. This procedure-which will pave the way to helping some 2,500 women in the U.K. have children related to them and avoid some terrible diseases-is, I believe, to be unreservedly welcomed. Unfortunately, some people seem to object regardless of the evidence and are willing to defend absurdly high standards of safety, standards that are not met by normal sexual reproduction, let alone by ARTs.

Mitochondrial disease can be very serious, causing conditions like Leigh's disease, a fatal infant encephalopathy, and others that waste muscles or cause diabetes and deafness.

\section{Future Generations}

Of course, this new technology is to some extent about consequences for "generations down the line" 29 _ but so what? This is true not only of all assisted reproductive technologies but also of all reproduction of whatever kind. This so-called uncharted territory (so called by Lisa Jardine, current chair of the HFEA, when she announced the HFEA's consultation on these issues in 2012) ${ }^{30}$ presents the usual trade-offs between benefits to people now and known unknowns concerning future dangers. The introduction of all new technologies involves uncertainty about longterm and unforeseen events.

This is, of course, also true of "normal" sexual reproduction-a very dangerous activity indeed, and one often described as a "genetic lottery." Human reproduction involves genes being recklessly combined-sometimes literally but always figuratively - in the dark, with unforeseeable consequences for the resulting children, parents, and the generations to come.

\section{Every year an estimated 7.9 million children-6 percent of total birth worldwide-are born with a serious birth defect of genetic or partially genetic origin. Additional hundreds of thousands more are born with seri- ous birth defects of post-conception origin, including maternal exposure to environmental agents, (teratogens) such as alcohol, rubella, syphilis and iodine deficiency that can harm a developing fetus. ${ }^{31}$}

It is doubtful that natural sexual reproduction, with its risk of sexually transmitted disease, its high abnormality rate in the resulting children, and its gross inefficiency in terms of the death and destruction of embryos (estimated to be one in three to one in five deaths per live birth), ${ }^{32}$ would ever have been approved by regulatory bodies if it had been invented as a reproductive technology rather than simply "found" as part of our evolved biology.

Of course, this is not a reason to add insult to injury, but it puts the peril of the uncharted future posed by this 
technology into some perspective. If the gold standard is sexual reproduction, new reproductive methods would have to be pretty bad to fail. MRT will prevent serious mitochondrial disease and the suffering it causes for women with mitochondrial disease, for their own children, and for countless future generations. As always, we have to balance possible unknown future risks with known future dangers.

\section{The Alternative to MRT Involves Greater Known Risk}

An important point is that, in the case of mitochondrial disease, we know that many women for many different reasons will continue to desire their own genetically related children and will continue to have them if denied or unable to access MRT. The denial of access to MRT will not prevent serious disease being transmitted indefinitely through the generations, whereas access to MRT can be expected significantly to reduce this risk. The choice here is not between a germline intervention that might go wrong and as a result perpetuate a problem indefinitely and a safe alternative. It is between such a technique and no current alternative for women who want their own genetically related offspring and who will also act so as to perpetuate the occurrence of disease.

\section{Safety and Uncertainty}

We have always to decide not what is safe but what is safe enough, given the balance of risks and benefits. As I noted with colleagues elsewhere:

[It] is worth reminding ourselves that uncertainty is the defining feature of knowledge-intensive societies and applies, quite obviously, to any procedure contemplated in humans for the first time. If impractically high precautionary thresholds were decisive we would not have vaccines, nor IVF, nor any other advance. Nothing is entirely safe. We have to decide what's "safe enough" given the balance of risks and benefits. Sometimes this decision must be left to those who wish to use the procedure and on whom the risk falls....

It is true that reproductive risks also fall on potential offspring. But that is true of all reproduction, and yet we do not ban it. Indeed, it is important to realise that we are already deeply engaged in a mass experiment ${ }^{33}$ on the quality of our gametes. This is particularly true for men, for whom ample evidence indicates that older age lowers the quality of gametes (most likely through the accumulation of DNA damage), with a clear correlation between older father's age and increased risk for several neuropsychiatric disorders like schizophrenia. ${ }^{34}$

\section{Three-Parent Families}

The "three genetic parents" label that has been applied by many commentators is also grossly misleading. The third-party DNA contained in the donated mitochondria makes up much less than 1 percent of the total genetic contribution and does not transmit any of the traits that confer the usual family resemblances and distinctive personal features in which both parents and children are interested. The mitochondria provide energy to cells and when they are diseased cause inheritable harm-hence the need for mitochondria replacement therapy. No identityconferring features are transmitted by the mitochondria.

In any event, to be a parent properly so called, as opposed to a mere progenitor, involves much more than a genetic contribution to the child and often does not entail a genetic contribution at all (for example, adoption, fostering, 
informal families, and nonpaternitymore of this anon).

Although children might be confused if they are told that they have three genetic parents, only a very confused person would think-let alone say-any such thing. If I were a child for whom the alternative to having some third-party DNA in my genomeDNA that influences nothing about my nature, save only my susceptibility to disease and suffering-was mitochondrial disease, I doubt I would be complaining about an identity crisis. If, on the other hand, I were condemned unnecessarily to a life of pain and illness, I would really have something to complain of, and indeed somebody to blame. And among those somebodies to blame would be anyone who opposes the introduction of this new technology.

\section{The Alleged Right to Know Genetic Origins}

A problem is often raised about whether or not resulting children have a right or a need to know the identity of the mitochondria donor. It is true that many people think that children have a right to know the identity of their progenitors. But this is dangerous nonsense: the right to access information about progenitors implies universal paternity testing, with all the mischief that this would entail. This is because of the widespread phenomenon known as nonpaternity.

"Nonpaternity" refers to cases in which children in a family are not in fact genetically related to the person they believe to be their father, who usually also believes he is the children's genetic father. Nonpaternity rates are quoted with wildly differing values (from less than 1\% to more than 30\%). A modest, and probably reliable, figure is 2 percent. However, even at a modest rate of 2 percent, nonpaternity rates in the United Kingdom account for more than 12,785 births registered annually to men who are not in fact the genetic father.

Is this a cause for concern? I doubt it, and I doubt even more the wisdom of any measures to "correct" this state of affairs. More mischief and anxiety would certainly be caused by recognizing a right to know, or indeed a duty to disclose, all contributors to a given genome. These will of course also include contributors in even earlier generations, and the contributions of our ape ancestors.

\section{Consent or Permission to Influence or Create a Particular Genome}

Finally we should consider the claim that because the future children who will be affected by use of MRT cannot consent, the requirement for informed consent of relevant parties to any medical intervention will be breached in the case of MRT. In its background briefing paper to the public meeting (held March 31 to April 1, 2015 ${ }^{35}$ ) referred to earlier, the United States Institute of Medicine refers to part of its task in considering ethical implications as including consideration of the "ethical issues in providing 'consent' or 'permission' to accept risks on behalf of a child who does not exist." 36

I am afraid that I fail to see any ethical issues that arise in connection with future generations as involving issues of consent. They do not, for the simple and sufficient reason that there are no such people in existence capable of either giving or withholding consent. All would be/might be parents make numerous decisions about issues that might affect their future children. They do this all the time without thinking about the consent of the children; how could they not do so? In most cases of 
sexual reproduction, decisions are made, first and foremost, about what genetic endowment is likely to result from a particular paring (or more complex combination) of sets of chromosomes; about where parents live and in what conditions (poverty, luxury, disease and health state, etc.) and hence about the environment into which any future children will be born; about maternal diet during pregnancy; and so on. Once children are born, decisions are made about what food and drink to give them and about what stimuli to provide (or withhold)—whether, for example, to allow children to ride bikes in the street or cross roads unaccompanied; and so on. All of this is necessarily accomplished without the necessity for the consent of the children-born or unborn, conceived or mere twinkles in their would-be parents' eyes.

To give just one personal example: I am a so-called baby boomer. That means, in my own case, that my Jewish parents living in the U.K. during World War II decided not to have any further children until the outcome of the war was clear; they decided it would not be in the interests of any further children that they had to be born into an environment controlled by German Nazis. As a result, I was born in 1945. I am sure they were not troubled by issues of my absent consent but, rather, were concerned with what would be in the best interests of any future children that they had, and indeed in their own interests. The same is true of all parents of existing children who lack capacity in the legal sense-that is, children who lack autonomy. Parents, when deciding what food to feed infants, what education to give them, what religious observance to inculcate, and what practices to forbid or to encourage, rarely ask for consent or even permission until children reach an age of discretion appropriate to the decision in question (and often not even then!). The same is true of medical and judicial decisionmaking on behalf of children who lack competence. The issue is not what the children want (although that may be relevant in some circumstances) but what is in their best interests.

Furthermore, in most cases, if the potential child's consent or assent were to be deemed necessary for creation, there will never ever be such an actual child. And because such consents cannot be obtained, it is in the interests of the child who would have been born, insofar as it makes any sense to talk of such interests, that its consent or assent should be deemed irrelevant. This is Derek Parfit's famous "nonidentity problem." 37 Thus utter disregard of the relevance of such consents is this potential child's only chance of existence, and therefore so long as the best guess is that the child's eventual life would not be intolerably ghastly, it would be in that child's interests to be created.

It is significant that those who raise issues of consent in relation to nonexistent beings only do so in circumstances in which they wish to claim that the children would not, or should not, have consented, rather than the reverse, and therefore should not have been born. But the opposite is true. If the interests and probable wishes of such children are to be considered, they will (if they are rational, and who is rational at minus more than nine months? - not one in a thousand) vote "yes please." What is clear is that this attitude cannot be of benefit to the child whose existence is at issue. It is better for all, surely, to ignore the issue of consents or assents and talk about the interests of the child that will be born, and make sure that child is as healthy as possible. That child will almost certainly be pleased to have been "spared" mitochondrial disease. It might well also 
wish to have had such a disease if that is the price of existence. Our dutyby that I mean every citizen's dutytherefore is, because neither child has a right to be the one created, surely to create the best possible child. That is what it is to act for the best, all things considered. ${ }^{38}$ This we have moral reasons to do, but they are not overriding reasons. Parents who choose otherwise, although not acting for the best, are still acting in ways with which it would be wrong to interfere. ${ }^{39}$

\section{Other Gene Modification Techniques}

\section{The Use of CRISPR/Cas9 in Embryos}

Many of the arguments rehearsed previously also apply to objections to other germline modification techniques. In a recent "statement on NIH funding of research using gene-editing technologies in human embryos" issued officially by the National Institutes of Health (NIH), Francis S. Collins, M.D., Ph.D., director of the NIH, stated: "The strong arguments against engaging in this activity remain. These include the serious and unquantifiable safety issues, ethical issues presented by altering the germline in a way that affects the next generation without their consent." 40

We have seen that these arguments are not only not strong but also pathetically weak. "Serious and unquantifiable" safety issues are present in all new technologies, and thus objections on these grounds need to be spelled out in detail and weighed against possible benefits. Moreover, consent issues, as we have noted, are irrelevant because consent is never available from the unborn or for things that might affect future generations. We have to address dangers to future generations and to the planet in quite another way; the raising of the issue of consent or its absence in such cases is, to put the point as politely as possible, irrelevant and misleading.

Collins concludes the quotation cited previously by mentioning "a current lack of compelling medical applications justifying the use of CRISPR/Cas9 in embryos" 41 as a further reason to ban them. If, and insofar as, this is true, it would constitute a powerful reason for caution in the case of CRISPR/Cas9 and other gene modification techniques in embryos but, we should note, would not constitute an objection to further research using human embryos in jurisdictions like the U.K. that permit human embryo research with the 14-day limitthat is, on embryos that have not developed beyond 14 days from creation and will not subsequently be implanted in a human and brought to birth.

\section{Transgenerational Epigenetic Inheritance}

As Sarah Reardon reported recently (June 25, 2015) in Nature News,

The US House of Representatives is wading into the debate over whether human embryos should be modified to introduce heritable changes. Its fiscal year 2016 spending bill for the US Food and Drug Administration (FDA) would prohibit the agency from spending money to evaluate research or clinical applications for such products.

In an unusual twist, the billintroduced on 17 June-would also direct the FDA to create a committee that includes religious experts to review a forthcoming report from the US Institute of Medicine (IOM). The IOM's analysis, which considers the ethics of creating embryos that have three genetic parents, was commissioned by the FDA. ${ }^{42}$

A parallel development has been the dramatic rise in interest in epigenetics and the increasing speculation that 
epigenetic inheritance can occur across generations. As the agenda for a workshop on "transgenerational epigenetic inheritance" hosted by the Company of Biologists announced:

The transmission of epigenetic states
across cell divisions in somatic tissues
is now well accepted and the mecha-
nisms are starting to be unveiled. The
extent to which epigenetic inheritance
can occur across generations is less
clear, but represents a very exciting
area with major implications for human
health, plant and animal breeding
and evolution. . . . Some of the out-
standing questions include: What trig-
gers heritable epigenetic changes and
how stably are they propagated? To
what extent can one exclude a DNA
sequence based mechanism? What are
the types of covariates that must be
taken into account in epidemiological
studies? What types of strategies will
be required to define the nature, extent
and mechanisms of non-Mendelian
transgenerational inheritance?43

What have so far escaped critical notice are the peculiar ethical issues raised by the possibility of epigenetic inheritance operating across generations. Many people, in the context of MRT, have become accustomed to hearing MRT referred to as creating so-called three-parent families because the provision of the-albeit minute-amount of inheritable material contained in the donated mitochondria is considered by those who use this term to constitute a form of parenting, and any number of parents above two consequently involved is judged by many to be objectionable. The question thus arises as to whether the source of the epigenetic material that may also be transferred "across generations" or the nature of the "thing" or the event that "triggers heritable epigenetic changes" might similarly qualify for parental status deriving from its originating role in the resulting human. And if it does, does it matter ethically whether or not that original source or trigger was a human individual or was produced by a human individual or by an inanimate or organic nonhuman trigger?

Oscar Wilde's formidable Lady Bracknell was, as usual, considerably ahead of the game. As she famously remarked, having received the news that Jack —or "Ernest" - Worthing was discovered in a handbag left in the cloakroom at a London railway terminus (the Brighton Line): "You can hardly imagine that I and Lord Bracknell would dream of allowing our only daughtera girl brought up with the utmost care-to marry into a cloak-room, and form an alliance with a parcel? Good morning, Mr. Worthing!"44 And later, "Until yesterday I had no idea that there were any families or persons whose origin was a Terminus." 45

So far there are many millions of humans who are blissfully unaware that their origins might include, or that their existence has been triggered by, the functional equivalent of a terminus or a parcel. Perhaps those who believe that having three (or more) genetic or indeed epigenetic "parents" is wrongful or problematic also share Lady Bracknell's social prejudices? If not, are we entitled to know what other objections there might be to such epigenetic ancestry and if such objections ground the implementation of preventive measures or criminal sanctions against these would-be or happen-tobe parents and license the prevention of such random, but socially disastrous, antecedents?

\section{Conclusion}

In his Life of Galileo, another playwright, Bertolt Brecht, gives a memorable insight into the justification of 
science to Galileo. Talking to Andrea Sarti-his former student and a scientific colleague who is about to smuggle the Discorsi, Galileo's heretical treatise on mechanics and local motion, out of Italy-Galileo says:

\begin{abstract}
A human race which shambles around in a pearly haze of superstition and old laws, too ignorant to develop its own powers, will never be able to develop those powers of nature which [scientists] are revealing to it. To what end are you working? Presumably for the principle that science's sole aim must be to lighten the burden of human existence. ${ }^{46}$
\end{abstract}

I agree with Brecht's Galileo, and most scientists, that the joy and the hope of science, although definitely not its sole purpose, is to lighten the burden of existence. This is what mitochondrial replacement therapy can, and in the U.K. hopefully will, achieve. The jury is perhaps still out on other gene modification techniques that affect the germline, but here we have a classic baby-and-bathwater problem, and we should be cautious about ruling out as unethical the future use of such techniques. In the case of MRT, let's celebrate the advent of a new and lifeenhancing therapy and the impressive science that enables this generation, and future ones, to correct the mistakes inherent in so-called normal sexual reproduction and to continue to lighten, where we can, the burden of human existence.

\section{Notes}

1. Harris J. On Cloning. London: Routledge; 2004: 8-9.

2. See Harris J. In Vitro fertilisation: The ethical issues. The Philosophical Quarterly 1983;33:132.

3. See note 1, Harris 2004, at ix.

4. Brian K. The amazing story of IVF: 35 years and five million babies later. The Guardian 2013 July 12; available at http:/ / www.theguardian. com/society/2013/jul/12/story-ivf-fivemillion-babies (last accessed 1 Apr 2015).

5. I organized a public lecture in Manchester shortly after the birth of Louise Brown was announced at which Patrick Steptoe spoke. I remember the university had to lay on special security for him because of the controversy the first test-tube baby had caused.

6. "Test-tube baby" Brown hails pioneers on 35th birthday. BBC News 2013 Jul 25; available at http: / / www.bbc.co.uk/news/health23448665 (last accessed 3 Apr 2015).

7. I have not forgotten that this particular baby was an angelic-looking sheep. The subsequent discussion follows lines I first developed back in 2004 in On Cloning (see note 1, Harris 2004).

8. Wilmut I, Schnieke AE, McWhir J, Kind AJ, Campbell KHS. Viable offspring derived from fetal and adult mammalian cells. Cloning and Stem Cells 2007;9(1):3-7.

9. See National Bioethics Advisory Commission. Cloning Human Beings: Report and Recommendations of the National Bioethics Advisory Commission. Rockville, MD; 1997 Jun; available at https:/ /bioethicsarchive.georgetown. $\mathrm{edu} / \mathrm{nbac} / \mathrm{pubs} / \mathrm{cloning} 1 /$ cloning.pdf (last accessed 8 Apr 2015).

10. Quoted from President Clinton's weekly radio broadcast, reported in Bioworld Today 1998 Jan 13;9(7). Interestingly, the National Bioethics Advisory Commission (see note 9) stated that it was unethical because it was unsafe. Clinton either misread his advisors' report or decided to add "morally unacceptable" on top of the fact that it was untested and unsafe, rather than simply stating that it was unsafe because it was untested.

11. Bush GW. President discusses stem cell research. The White House; 2001 Aug 9; available at http://georgewbush-whitehouse.archives. gov/news/releases/2001/08/20010809-2.html (last accessed 8 Apr 2015).

12. Compassion in World Farming. Farm Animal Cloning: A Compassion in World Farming Report; 2010, at 24; available at https://www.ciwf. org.uk/media/3816935/farm-animal-cloningreport.pdf (last accessed 8 Apr 2015).

13. Reported in BioCentury, the Bernstein Report on BioBusiness 1998 Jan 19.

14. The European Parliament. Resolution on Cloning, 1997 O.J. (C 115) 14.4/92 (1997 Mar 12), at paragraph $B$ and clause 1.

15. Based on birthrate figures from http://www. ecology.com/birth-death-rates / (last accessed 3 Apr 2015).

16. Oral presentation by Marcy Darnovsky at a workshop of the United States Institute of 
Medicine of the National Academies Board on Health Sciences Policy entitled "Ethical and Social Policy Considerations of Novel Techniques for Prevention of Maternal Transmission of Mitochondrial DNA Diseases," Washington, DC, March 31-April 1, 2015. I am relying on my recollection of what she said in my presence at the meeting. See also Darnovsky M. World view column: A slippery slope to human germline modification. Nature 2013;499:127. doi:10.1038/ 499127a; available at http://www.nature. com/polopoly_fs/1.13358!/menu/main/ topColumns / topLeftColumn / pdf / 499127a.pdf (last accessed 7 Apr 2015).

17. Harris J. Wonderwoman and Superman: The Ethics of Human Biotechnology. Oxford: Oxford University Press; 1992, chap. 8.

18. Vogel G, Stokstad E. U.K. Parliament approves controversial three-parent mitochondrial gene therapy. ScienceInsider 2015 Feb 3; available at http:/ / news.sciencemag.org/biology/2015/ 02/u-k-parliament-approves-controversialthree-parent-mitochondrial-gene-therapy (last accessed 7 Apr 2015).

19. The National Academies. Project information: Ethical and Social Policy Considerations of Novel Techniques for Prevention of Maternal Transmission of Mitochondrial DNA Diseases. National Academies Current Projects; 2015; available at http:/ / www8.nationalacademies.org/ $\mathrm{cp} /$ projectview.aspx?key $=49648$ (last accessed 7 Apr 2015).

20. UN Educational, Scientific and Cultural Organisation (UNESCO). Universal Declaration on the Human Genome and Human Rights; 1997 Nov 11; available at http://www.refworld. org/docid/404226144.html (last accessed 9 Apr 2015). This document absurdly endorses "the preservation of the human genome as common heritage of humanity."

21. Harris J. Enhancing Evolution. Princeton, NJ, and Oxford: Princeton University Press; 2007.

22. Dawkins R. The Selfish Gene. Oxford: Oxford University Press; 1976.

23. See note 21, Harris 2007.

24. Cyranoski D, Reardon S. Chinese scientists genetically modify human embryos. Nature 2015 Apr 22; available at http: / / www.nature. com/news/chinese-scientists-geneticallymodify-human-embryos-1.17378 (last accessed 25 Apr 2015). See also Reardon S. Ethics of embryo editing paper divides scientists. Nature 2015 Apr 24; available at http:/ /www.nature. com/news/ethics-of-embryo-editing-paperdivides-scientists-1.17410 (last accessed 25 Apr 2015), for some of my comments on this development.
25. Baltimore D, Berg P, Botchan M, Carroll D, Charo RA, Church G, et al. A prudent path forward for genomic engineering and germline gene modification. Science; forthcoming; available at http://www.sciencemag.org/ content/early/2015/03/18/science.aab1028. full (last accessed 26 Mar 2015). Cyranoski D. Ethics of embryo editing divides scientists. Nature 2015 Mar;519:272; available at http:/ / www.nature.com/news/ethics-of-embryoediting-divides-scientists-1.17131 (last accessed 26 Mar 2015). Lanphier E, Urnov F, Haecker SE, Werner M, Smolenski J. Don't edit the human germ line. Nature 2015 Mar;519:410-11; available at http:/ /www.nature.com/news / don-t-edit-the-human-germ-line-1.17111 (last accessed 26 Mar 2015). Vogel G. Embryo engineering alarm. Science 2015;347(6228):1301; available at http://www.sciencemag.org/ content/347/6228/1301.full (last accessed 26 Mar 2015).

26. See note 25 , Baltimore et al. forthcoming, at 2 .

27. The Human Fertilization and Embryology Act 1990 c.37; available at http://www. legislation.gov.uk/ukpga/1990/37/contents (last accessed 7 Apr 2015). See also the amendment by the Human Fertilization and Embryology Act 2008 c.22; available at http:/ / www.legislation.gov.uk/ukpga/2008/22/ contents (last accessed 7 Apr 2015).

28. Department of Health and Social Security. Report of the Committee of Inquiry into Human Fertilisation and Embryology (The Warnock Report); Cm 9314; 1984 July; available at http: / / www.hfea.gov.uk/docs/Warnock_ Report_of_the_Committee_of_Inquiry_into_ Human_Fertilisation_and_Embryology_1984. pdf (last accessed 7 Apr 2015).

29. Lisa Jardine, quoted in Sample I. Regulator to consult public over plans for new fertility treatments. The Guardian 2012 Sep 17; available at http://www.theguardian.com/science/2012/ sep/17/genetics-embryo-dna-mitochondrialdisease?newsfeed=true (last accessed 8 Apr 2015).

30. See note 29, Sample 2012.

31. The March of Dimes Birth Defects Foundation. March of Dimes Global Report on Birth Defects. New York: White Plains; 2006.

32. Boklage CE. Survival probability of human conceptions from fertilization to term. International Journal of Fertility 1990;35(2): 75-94. See also Leridon H. Human Fertility: The Basic Components. Chicago: University of Chicago Press; 1977; Green RM. The Human Embryo Research Debates. New York: Oxford University Press; 2001, at n185. A figure of 70 percent total embryo loss is confirmed 
by Macklon NS, Geraedts JP, Fauser BC. Conception to ongoing pregnancy: The "black box" of early pregnancy loss. Human Reproduction Update 2002;8(4):333-43. Edmonds DK, Lindsay KS, Miller JF, Williamson E, Wood PJ. Early embryonic mortality in women. Obstetrical \& Gynecological Survey 1983;38(7):433-4. Edmonds et al. give a figure of 61.9 percent loss before 12 weeks, but because this figure does not include embryo loss before implantation or from miscarriage after 12 weeks, the figure of 80 percent may be more accurate. Roberts CJ, Lowe CR. Where have all the conceptions gone? Lancet 1975;1:498-9. See also Bovens L. The rhythm method and embryonic death. Journal of Medical Ethics 2006;32(6):355-7.

33. Kong A, Frigge ML, Masson G, Besenbacher S, Sulem P, Magnusson G, et al. Rate of de novo mutations and the importance of father's age to disease risk. Nature 2012;488(7412):471-5.

34. Palacios-González C, Harris J, Testa G. Multiplex parenting: IVG and the generations to come. Journal of Medical Ethics 2014; 40(11):752-8.doi:10.1136/medethics2013-101810.

35. Institute of Medicine of the National Academies. Meeting \#2: Public Workshop of the Committee on Ethical and Social Policy Considerations of Novel Techniques for Prevention of Maternal Transmission of Mitochondrial DNA Diseases; available at http:/ / www.iom.edu/Activities / Research / MitoEthics/2015-MAR-31.aspx (last accessed 7 Apr 2015).

36. See note 19, the National Academies 2015.

37. Parfit D. Reasons and Persons. Oxford: Clarendon Press; 1984, at part 4, chap. 16, 351-77.
38. I develop the importance of this imperative"to act for the best all things considered" - in my new book: Harris J. How to Be Good. Oxford: Oxford University Press; forthcoming.

39. I develop this idea in Harris forthcoming (see note 38 ) and in Harris J. Rights and reproductive choice. In: Harris J, Holm S, eds. The Future of Human Reproduction: Choice and Regulation. Oxford: Oxford University Press; 1998:5-37. See also Harris J. The Value of Life. London: Routledge; 1985.

40. National Institutes of Health. Statement on $\mathrm{NIH}$ funding of research using gene-editing technologies in human embryos. The NIH Director; 2015 Apr 29; available at http:// www.nih.gov/about/director / 04292015 statement_gene_editing_technologies.htm (last accessed 18 May 2015).

41. See note 40, NIH 2015.

42. Reardon S. US Congress moves to block human-embryo editing. Nature 2015 June 25; available at http://www.nature.com/news / us-congress-moves-to-block-human-embryoediting-1.17858 (last accessed 27 June 2015).

43. The Company of Biologists. Workshops: Transgenerational Epigenetic Inheritance; 2015 Oct 4-7; available at http:/ / workshops. biologists.com/transgenerational-epigeneticinheritance/ (last accessed 27 June 2015).

44. Excerpt from Wilde O. The Importance of Being Earnest: A Trivial Comedy for Serious People. iBooks; available at https://itunes. apple.com/WebObjects/MZStore.woa/wa / viewBook?id=4FFC4D4B8607BEFA334DCC 3173E9E585.

45. See note 44, Wilde.

46. Brecht B. Life of Galileo. Willett J, trans. London: Methuen; 1994, at scene 14, 108-9. 